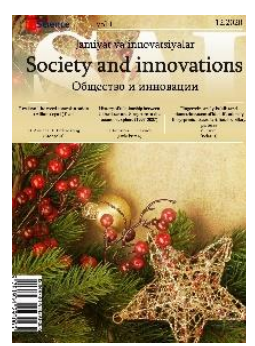

\title{
Results of the weed control in onion (Allium Cepa L.) field
}

\author{
Dr. Ariunaa ${ }^{1}$, Erdenenzorig T. ${ }^{2}$, Dondov B. ${ }^{3}$
}

Plant Protection Research Institute

\begin{tabular}{l} 
ARTICLE INFO \\
\hline Article history: \\
Received September 2020 \\
Received in revised form \\
15 October 2020 \\
Accepted 15 November 2020 \\
Available online \\
31 December 2020
\end{tabular}

Keywords:

Pendimethalin

Oxyfluorfen

Herbicide

Yield

Onion

\begin{abstract}
Our country has provided about $52 \%$ of vegetables from domestic production, the rest part imported others from outside. Thus, imports of potatoes and vegetables have been reduced last year, for this reason, main vegetable seeds, were produced domestically and provided over 80 percent of the country's demand. In the future domestic production demand of vegetable goal set working to provide by 100 percent from government our country in this connection issues urgent need to solve sowing seeds, variety supply, seed production, and plant protection.

According to our research, during the growing season, 150350 weeds growing per $1 \mathrm{~m}^{2}$ of rounded onions shows that the amount of crop damage is relatively high. For the purpose of control against weeds in the onion field with 3 repetitions of 7 variants of 2 types of herbicides are conducted experimental research. These include; pre-emergent Estamp (Stomp) herbicide applied in doses $2.5 ; 3.5 \mathrm{l}$ /ha that controls all types of weeds, but showed results of $65.2-72.4 \%$. The growing season during a selective post-emergent of Gaur herbicide in doses 0.7; $0.91 /$ ha used against broadleaf and grassy weeds that became clear of weed species density reduced by $92.7-93.4 \%$. It was tested in this study Pendimethalin, 33\% + Oxyfluorfen $24 \%$ mixture herbicides have reduced the number of weeds by $92.4-$ $94.1 \%$.
\end{abstract}

2181-1415/C) 2020 in Science LLC.

This is an open access article under the Attribution 4.0 International (CC BY 4.0) license (https://creativecommons.org/licenses/by/4.0/deed.ru)

\footnotetext{
${ }^{1}$ Doctor of Agricultural Science, Weed Research Laboratory, Plant Protection Research Institute (PPRI), Ulaanbaatar, Mongolia

Email: ariunaa.ochir14@gmail.com

${ }^{2}$ Master, Plant Protection Research Institute (PPRI), Ulaanbaatar, Mongolia

${ }^{3}$ Associate professor, Plant Protection Research Institute (PPRI), Ulaanbaatar, Mongolia
} 


\section{Результаты борьбы с сорняками на луковом поле (Allium Cepa L.)}

\begin{tabular}{l}
\hline Ключевые слова: \\
Пендиметалин \\
Оксифлуорфен \\
Гербицид \\
Уступать \\
Лук.
\end{tabular}

\section{АННОТАЦИЯ}

Около 52\% овощной продукции Монголии
выращивается самой, остальная часть импортируется из соседних стран. Однако из-за сокращения импорта 2020 году 80 \% овощей была выращена в стране. Правительством страны поставлена цель обеспечить население овощной продукцией на 100 \% в последующие годы, в связи с чем возникает острая необходимость в решении проблемы посева семян, предложения сортов, производства семян и защиты растений от вредителей.

Согласно нашим исследованиям, в период вегетации 150 350 сорняков, произрастающих на 1м2 лука, свидетельствует об относительно высокой степени поражения урожая. С целью борьбы с сорняками на луковом поле в 3-х повторах 7 вариантов 2-х видов гербицидов проводятся экспериментальные исследования. Они включают; довсходовый гербицид Estamp (Stomp), применяемый в дозах 2,5; 3,5 л / га, что подавляет все виды сорняков, но дает результат $65,2-72,4 \%$. Вегетационный период во время селективной послевсходовой обработки гербицида Gaur в дозах 0,7; 0,9 л / га против широколиственных и травянистых сорняков, очищенных от сорняков, густота снизилась на 92,7-93,4\%. В этом исследовании было испытано, что смесь гербицидов пендиметалин $33 \%+$ оксифлуорфен $24 \%$ снизила количество сорняков на 92,4-94,1\%.

\section{INTRODUCTION}

Onion (Allium cepa L.), is an important species belonging to family Alliaceae. It is an indispensable item in every kitchen as vegetable and condiment used to flavor many of the food kinds of stuff. Therefore, onion is popularly known as 'Queen of the kitchen'. It is one of the most important vegetable crops in the world with a total production of about 61 million tonnes (FAO, 2006). Onion (Allium cepa L.) is an important export-oriented vegetable crop, valued for its distinctive flavor and spiciness. Being an indispensable ingredient of both vegetarian and non-vegetarian diets, its demand is getting increased as the only vegetable spices. India contributes a $21.5 \%$ share in world onion production although it globally ranks ninth in terms of productivity (FAOSTAT 2019). The productivity of onion is reasonably low and remains almost static with a negligible variation for a long period. Weed infestation is one of the vital limiting factors that cause comparatively more losses than those caused due to insect pests and diseases. Crop losses due to weeds vary from 30 to $95 \%$ in onion (Praksh et al. 2000, Rameshwar et al. 2001; UditKumar 2014). Onion is considered to be the second most important vegetable crop grown in the world next to the tomato. In the world, India stands first in the area and ranks second to China in production; the total area in India under onion cultivation during 2012-13 was 10.51 
lakh hectare with a production of 168.13 lakh tons and productivity of $16 \mathrm{t}$ ha-1 (Tiwary, 2014). Onion exhibits greater susceptibility to weed competition as compared to other crops due to its inherent characteristics such as slow germination, extremely slow growth in the initial stages, short stature, non-branching habit, sparse foliage, and shallow root system. This favors quick and fast growth of weeds in the initial stages and competition thus tends to be severe. Moreover, the use of a liberal dose of FYM, fertilizers, and frequent irrigations creates favorable conditions for weed growth (Singh et al., 1986). According to the results of a study conducted in similar climates in Russia, [8] 33.0\% of turnip crops, 26\% of tomatoes and 5.2-33.0\% of onion yields are lost due to weeds [9]. In onion field application of Fusillade-super herbicide at a dose of 2.0-2.5 l/ha increased crop yield by 22.3-28.5\% and increased the crop yield by $13 \%$ for the variants with agro-technical treatments (Ariunaa 0, 2004-2006). Weed control efficiency, plant height, Number of leaves, leaf area, average bulb weight, total yield and zero per cent weed control index in weed free check followed by with application of pre-emergence spray of Oxyfluorfen $23.5 \%$ EC @ $0.25 \mathrm{~kg}$ ai ha-1 + postemergence spray of $1 / 2$ dose of (Quizalofop ethyl 5\% EC @ $0.05 \mathrm{~kg}$ ha-1 + 0xyfluorfen $23.5 \%$ EC @ $0.25 \mathrm{~kg}$ ai ha-1) at 40 DAT along with highest cost benefit ratio [11]. Application of Oxyfluorfen + one hand weeding recorded the lowest number of monocot weeds $\left(26.33 / \mathrm{m}^{2}\right)$, fresh weight of weeds $\left(40.08 \mathrm{~g} / \mathrm{m}^{2}\right)$ and dry weight of weeds $\left(14 \mathrm{~g} / \mathrm{m}^{2}\right)$ (Sahoo B.B, Tripathy P, 2019).

Weed control is one of the most difficult tasks in crop production agriculture that accounts for a considerable share of the cost involved in agricultural production. There are many methods for weed management, but out of those methods, chemical methods are the most popular. To sustainably increase the yield of vegetables, including onions for planting varieties and cultivation techniques do regularly and the selection of suitable regions is of great importance. Therefore, the aim of the experiment was to develop a control method suitable for the biological characteristics of dominate weeds against to choice useful dose, treatment do time and herbicide type in onion field.

\section{MATERIALS AND METHODS}

Experimental site

- A field experiment was conducted at the SDC's Mongolian Vegetable Project experimental site located in Bornuur soum of Tuv province.

- The field experiment was conducted during the growing season 2017-2018, which is located at $\mathrm{N} 48^{\circ} 486530$ latitudes, E 1060265387 longitude with an altitude 1350 meters above mean sea level.

\section{Climatic conditions}

- The meteorological data for 2017-2018 and the mean of the previous 10 years were collected from the Institute of Meteorology, Hydrology, and Environment, Mongolia, and presented in Figure 1. 
Figure 1.

Climatic factors during the year of 2017 and 2018.

(Bornuur soum of Tuv province).

\section{Climatic parameters of Bornuur soum Tuv province}

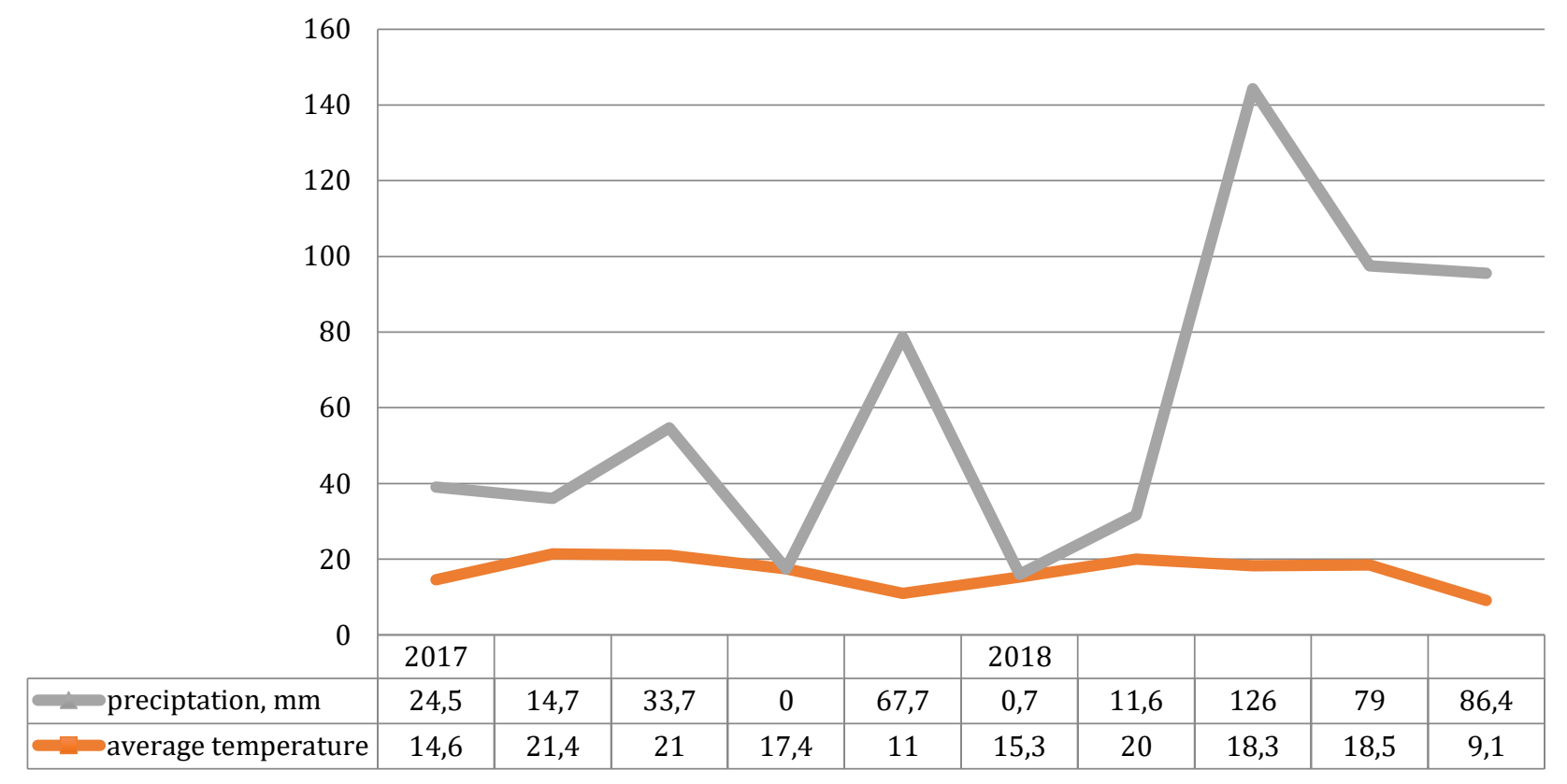

- According to the graph, in 2017 the weather parameters were slightly warmer than in 2018, and the temperature was increased by 4.1, the number of days above 30 degrees was 11 days higher, and the amount of precipitation was $14.8 \mathrm{~mm}$ low /Graph 1/. In May 2018, the air temperature was $12.4^{\circ} \mathrm{C}$ and then the long-term average by $8.15^{\circ} \mathrm{C}$ lower but observed to prolong the growth period of young onions.

- Of onion crop the growing season has fall $209 \mathrm{~mm}$ of precipitation (7-8 months) and that $70 \%$ of the annual precipitation. Those have had a positive effect on crop growth.

Soil and its characteristics

- The experimental field was conducted on medium-deep brown soil and the sandyloam texture with a pH from 6.5 to 7.0.

\section{Experimental details}

The experiment consisted of seven herbicide variant viz.., Pendimethalin, Oxyfluorfen, Pendimethalin 30\% EC + Oxyfluorfen 24.0\% EC in different concentrations with control.

The onion variety Stutt garter was sown at $15 \times 10 \mathrm{~cm}$ spacing from 20 to 25 th May of the year 2017-18. The experimental design was split-plot with a randomized complete block arrangement with three replications. 
Table 1.

The common name, trade name and chemical names of herbicide

\begin{tabular}{|l|l|l|l|}
\hline Common name & $\begin{array}{l}\text { Active } \\
\text { gradient }\end{array}$ & $\begin{array}{l}\text { Trade } \\
\text { name }\end{array}$ & Chemical name \\
\hline Pendimethalin & $33 \%$ EC & Estamp & $\begin{array}{l}\text { 3,4-dimethyl-2,6-dinitro- } N \text { - } \\
\text { pentan-3-ylaniline }\end{array}$ \\
\hline Oxyfluorfen & $24 \%$ EC & Gaur & $\begin{array}{l}\text { 2-chloro-1-(3-ethoxy-4- } \\
\text { nitrophenoxy)-4- } \\
\text { (trifluoromethyl)benzene }\end{array}$ \\
\hline
\end{tabular}

The experimental field consists of seven variants viz.,

1. Control

2. Pre-emergence spray of Pendimethalin 30\% EC $3.0 \mathrm{l} / \mathrm{ha}$

3. Pre-emergence spray of Pendimethalin 30\% EC $3.5 \mathrm{l} / \mathrm{ha}$

4. Post-emergence spray of Oxyfluorfen 24\% EC $0.7 \mathrm{l} / \mathrm{ha}$

5. Post-emergence spray of Oxyfluorfen $24 \%$ EC 0.9 l/ha

6. Pre-emergence spray of Pendimethalin 30\% EC + Post-emergence spray of Oxyfluorfen $24.0 \%$ EC $3.0+0.7$ l/ha

7. Pre-emergence spray of Pendimethalin 30\% EC + Post-emergence spray of Oxyfluorfen 24\% EC $3.5+0.9$ l/ha

Weed parameters

- We determined the weed species composition and density in the onion field by methods N.N.Libershtein and A.M.Tulikow, 1980. Counting of weeds conducted at two locations within each plot, using a 0.5 yard2 quadrant [13].

- Weed numbers were taken, on 20,40, 60 days after sowing from one square meter area.

Data on weeds was recorded 14, 21, and 30 DAS in each plot in quadrates, each measuring $50 \times 50 \mathrm{~cm}$. The weeds in every frame were conducted weed density count and classified into biological groups. Before and after spaying the herbicides $(7,14$, and 21 days) the $1 \mathrm{~m} 2$ area selected from each experimental plot in four replications to establish weed density and mass during a tillering stage of onion. Weed control efficiency was calculated using the following formula;

WCE $(\%)=\frac{W_{2} * 100}{W_{1}}-100$

WCE (\%)- Weed control efficiency

- Herbicide applications were made to pre-emergence, post-emergence of onions with a hand sprayer equipped with Flat Fan nozzle at a pressure of $291 \mathrm{kPa}$.

- Onions were harvested by hand using a small hand-hoe. Fresh weights of onion bulbs were recorded after harvest for a one-meter quadrate from each plot.

\section{Statistical analysis}

- Fisher's method of analysis of variance was applied for the analysis and interpretation of data was made as per the method of Dospehov BA (1973). The relative yield of each experimental plot was calculated as a percent of the corresponding weed-free yield for each level the main factor. 


\section{RESULT AND DISCUSSIONS \\ Weed species distribution.}

Figure 2.

\section{The ratio of biological groups of weeds, in $\%$}

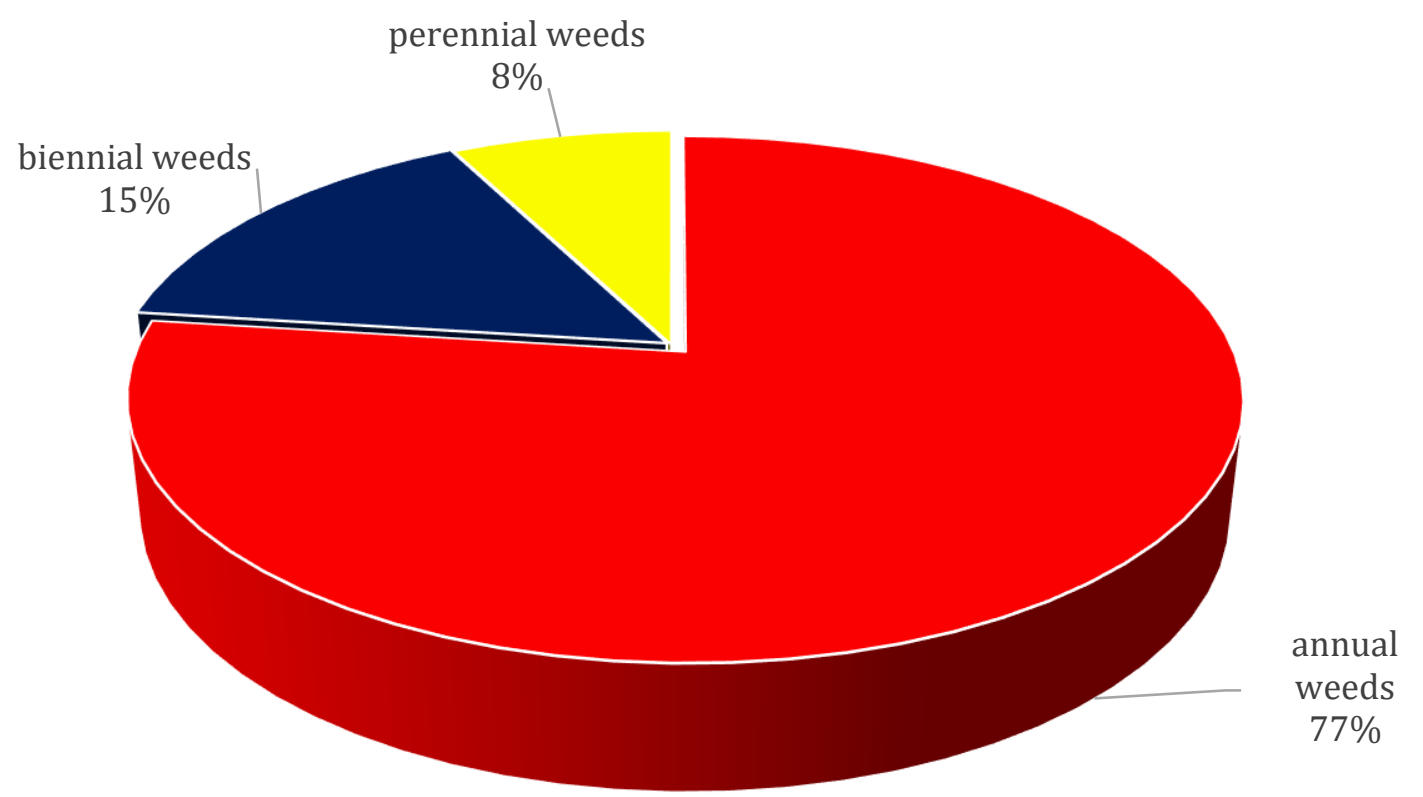

The study years in 2017 to 2018 , of the 13 species of weeds belonging to 10 families, 12 genera including $77.5 \%$ annual, $22.5 \%$ perennial weeds have occurred during the onion growing period. The total combined density of weed species, ranged from 108-252 weeds per square meter, in the experimental-production field at Bornuur sum, Tuv province. The major grassy weeds For example; Common millet- (Panicum miliaceum L), Couch grass(Agropyron repens L) sp and broadleaf weeds Redroot Pigweed- (Amaranthus retroflexus $L$ ), lambs quarters- (Chenopodium album L), Black bindweed- (Polygonum convolvulus L), Mallow weed- (Malva mochileviensis Down), Field bindweed - (Convolvulus arvensis L), Dwarf bifurcate cinquefoil-(Potentilla bifurca L), Perennial Sowthistle-(Sonchus arvensis $L$ ) weeds have been distributed in the onion field. The crop field was dominated more with the monocot weeds /Figure 2/. According to a study conducted in Russia, when 250-400 weeds grow on $1 \mathrm{~m} 2$ of onions and carrots, the crops completely lose their yield $[8,15]$. Also as in our country in vegetable fields is relatively high the amount of harm caused by weed.

\section{Effect on weed control efficiency.}

The Pendimethalin (33\%) herbicide at doses 3.0-3.5 l/ha was applied in preemergence in onion field to control annual grasses and certain broadleaf weeds. Postemergence herbicide Oxyfluorfen (24\%) were applied at 0.7-0.9 l/ha have reduced the number of weeds by $92.7-93.4 \%$ and Pendimethalin, 33\% + Oxyfluorfen $24 \%$ mixture herbicides applied at 3.0+0.7 $\mathrm{l} /$ ha have reduced the number of weeds by $92.4-94.1 \%$ and presented in Table 1 . The results demonstrate a slight benefit of the Pendimethalin, 33\% weed control program compared to the Oxyfluorfen (24\%) herbicide in terms of weed control efficacy. 
Table 2.

Effect of the herbicides applied against weeds in onions (2017-2018)

\begin{tabular}{|c|c|c|c|c|c|c|}
\hline \multirow[b]{2}{*}{ № } & \multirow[b]{2}{*}{$\begin{array}{l}\text { Variant of } \\
\text { herbicides }\end{array}$} & \multirow[b]{2}{*}{$\begin{array}{c}\text { Herbicid } \\
\text { e doses, } \\
\text { (l/ha) }\end{array}$} & \multicolumn{2}{|c|}{ Herbicide to spray } & \multirow[b]{2}{*}{$\begin{array}{c}\text { Weed } \\
\text { density, } \\
\text { (weeds/ } \\
\mathrm{m}^{2} \text { ) }\end{array}$} & \multirow[b]{2}{*}{$\begin{array}{l}\text { Weed control } \\
\text { efficiency, (\%) }\end{array}$} \\
\hline & & & $\begin{array}{c}\text { before } \\
\text { in } \\
\text { weeds/ } \\
m^{2}\end{array}$ & $\begin{array}{c}\text { after in } \\
\text { weeds } / \\
m^{2}\end{array}$ & & \\
\hline 1. & Control & 0 & 172 & 328.0 & - & - \\
\hline \multirow{2}{*}{2.} & \multirow{2}{*}{$\begin{array}{c}\text { Pendimethalin, } \\
33 \%\end{array}$} & 3.0 & 158 & - & - & 65.2 \\
\hline & & 3.5 & 161 & - & - & 72.4 \\
\hline \multirow[b]{2}{*}{3.} & \multirow[b]{2}{*}{ Oxyfluorfen $24 \%$} & 0.7 & 193 & 14 & 179 & 92.7 \\
\hline & & 0.9 & 138 & 9 & 129 & 93.4 \\
\hline 4. & $\begin{array}{c}\text { Pendimethalin, } \\
33 \%+ \\
\text { Oxyfluorfen } 24 \%\end{array}$ & $3.0+0.7$ & 106 & 8 & 98 & 92.4 \\
\hline 5. & $\begin{array}{c}\text { Pendimethalin, } \\
33 \%+ \\
\text { Oxyfluorfen } 24 \%\end{array}$ & $3.5+0.9$ & 102 & 6 & 96 & 94.1 \\
\hline
\end{tabular}

The table shows that the applied herbicides in the onion field reduced the number of weeds per $1 \mathrm{~m}^{2}$ by 96-179. The data presented on weed control efficiency in onion (Table 2) revealed significant variations among the treatments. In weed management treatments highest weed control efficiency (94.1\%) was recorded with the treatment Pendimethalin 30\% EC 3.5 l/ha + 0xyfluorfen 24\% EC 0.9 l/ha and lowest weed control efficiency (38.53\%) was recorded with treatment Pendimethalin 30\% EC 3.01/ha. Of onion fields, Demetra herbicides /0.4, 0.5l/ha doses/ broadleaved weeds against applied of weeds number by 35,1-38,02\% and Miura herbicides 0.8l/ha doses grass weeds against applied by $91,5 \%$ reduced [16] the results are in agreement with researchers.

Pendimethalin 3.5l/ha+ Oxyfluorfen 0.9l/ha was significantly better in increasing the bulb diameter, bulb weight, bulb yield and loss of bulb weight when compared with the control. That is te air temperature in 2018 was lower by $4.1{ }^{\circ} \mathrm{C}$ compared to the previous year, which had a positive effect on the growth of onion bulbs and the amount of heat required for the crops. Compared to the results of the 2017 survey, the size and weight of bulbs were relatively high, as the weight of one onion in the non-controlled version varied between 45-91g. These the resuts in agreement other researchers. The reduction in bulb yield varies to the extent of 48 to 85 percent depending upon the duration, intensity of weed growth, and weed competition (Bhalla, 1978). The pooled average bulb weight in onion varies from 44.75g (T1-Control) to $92.65 \mathrm{~g}$ (T2-Weed free check). Significantly heaviest bulb was recorded in T2 $(92.65 \mathrm{~g})$ than rest of the treatments except T6 (86.23 g), T4 (86.19 g), T8 (85.88 g), T9 (84.21g) and T7 (82.82 g), which were statistically at par Sahoo S.K et all, 2017/ [11]. In the onion field, the herbicide has been applied against weeds increased yields by 2.4-32.7 ha compared to controls (Table 3). 
Table 3.

Effects of herbicides on yield of onion /2017-2018/

\begin{tabular}{|c|c|c|c|c|c|}
\hline \multirow[t]{2}{*}{ № } & \multirow[b]{2}{*}{ Variants } & \multirow[b]{2}{*}{$\begin{array}{l}\text { Herbicides } \\
\text { doses } 1 / \text { ha }\end{array}$} & \multicolumn{2}{|c|}{ Yields, cent/hectare } & \multirow{2}{*}{$\begin{array}{l}\text { Additional } \\
\text { yields, } \\
\text { (average) } \\
\text { cent/ha }\end{array}$} \\
\hline & & & 2017 & 2018 & \\
\hline 1 & Control & - & 106.3 & 84.5 & - \\
\hline \multirow{2}{*}{$\begin{array}{l}2 \\
3\end{array}$} & \multirow{2}{*}{$\begin{array}{l}\text { Pendimethalin, } \\
33 \%\end{array}$} & 3.0 & 107.0 & 88.7 & 2.4 \\
\hline & & 3.5 & 109.2 & 91.4 & 8.3 \\
\hline \multirow{2}{*}{$\begin{array}{l}4 \\
5\end{array}$} & \multirow[t]{2}{*}{ Oxyfluorfen $24 \%$} & 0.7 & 114.2 & 102.0 & 12.7 \\
\hline & & 0.9 & 116.3 & 107.0 & 27.5 \\
\hline 6 & $\begin{array}{l}\text { Pendimethalin, } \\
33 \% \\
\text { Oxyfluorfen } 24 \%\end{array}$ & $3.0+0.7$ & 117.5 & $' 108.4$ & 17.5 \\
\hline 7 & $\begin{array}{l}\text { Pendimethalin, } \\
33 \% \\
\text { Oxyfluorfen } 24 \%\end{array}$ & $3.5+0.9$ & 118.3 & 111.2 & 32.7 \\
\hline
\end{tabular}

For the statistical correlation analyzed of elements of yield structure, then correlation a yield from the number of weeds $|r=0.4|$ that is medium according to the regression equation, while as the green mass of weeds in the area increases, the weight of the crop bulbs reduces and the yield decreased by 11.6 percent. The experimental increase in weeds density then decreased crop bulb weight and biological yield onion. Therefore, crop rotation, proper herbicide application and herbicide rotation should be used obligatory in onion fields.

\section{CONCLUSIONS}

Our for the survey indicated the effect of weeds of harm threshold, management in onion. This study Pendimethalin 30\% EC 3.5 l/ha + Oxyfluorfen 24\% EC 0.9 l/ha distinguished for the most appropriate method for effective weed management and profitable cultivation of onion. Other methods were either fewer profit earners or are labor expensive. Spraying of pre-emergence herbicides keeps the crop in weed-free conditions during the early stages the application of post-emergence herbicides helps to reduce the cost of weeding and keep the weed population below economic threshold level throughout the crop growth period. In this case, onion producers must use all available technologies, considering both socioeconomic and environmental efficiency.

\section{ACKNOWLEDGMENT}

To perform this research provided all opportunities project leader Associate Professor B.Dondov and Academic Council of Institute Plant Protection, and of weed laboratory colleagues to express thank you very much. 


\section{References}

1. FAO (2006). FAO Statistics Division, http://faostat.fao.org/default.aspx

2. FAOSTAT. 2019. Website (http://faostat3.fao.org/home/E)accessed on 13th January, 2019.

3. Praksh V, Pandey AK, Singh RD and Mani VP. 2000. IntegratedWeed Management in winter onion (Allium cepa L.) under Mid-hill conditions of North western Himalayas. IndianJournal of Agronomy45: 816-821.

4. Rameshwar S, Vishal GD and Singh G. 2001. Crop weedscompetition study in onion (Allium cepa L.) under drytemperature high hills condition of Himachal Pradesh.Indian Journal of Weed science33: 168-170.

5. Udit Kumar. 2014. Weed management studies in onion (Alliumcepa L.). Asian Journal of Horticulture9(2): 426-430.

6. Tiwary, R. K. 2014. Indian Horticulture Database2013, NHB, Gurgaon, India, pp-160.

7. Singh, R., Sinha, K.P. and Singh, S.P. 1986. Comparative efficacy of herbicides and hand weeding for control of weeds in onion. Haryana J. Hort. Sci., 15 (1 \& 2: 76-82.

8. Воеводин А.В.Бешанов А.B, 1972, Минимальная обработка почв с использованием гербицидов. Москва. стр 21-24,

9. Amarjargal B, 1996, “Совершенствование мер борьбы с сорняками на посевах капусты и моркови в ЦЗЗ Монголии” Автореф. дисс. на соис. уч.степ. канд СХ. Наук, УБ.

10. Ariunaa 0, 2004-2006, Integrated weed management in onion (Allium cepa L.) of conditions Mongolian.

11. Sahoo, S. K. Chakravorty, S. Soren, L. Mishra, C. and Sahoo, B.B., Krishi Vigyan Kendra, 2017; Effect of weed management on growth and yield of onion (Allium cepa L,) Deogarh -768, Odisha. 13-02: 210

12. Sahoo B.B, and Tripathy P, 2019. Scheduling weed management practices for improving weed controlefficiency and bulb yield in onion. Sambalpur,Odisha 768025, India. Indian Journal of Weed Science 51(3): 308-311,

13. Либерштейн.И.И, Туликов.А.М, 1980, “Актуальные вопросы борьбы с сорными растениями". Москва

14. Dospehov BA (1973). "Technique of field experience". Moscow. p:187-206

15. Tripathy, P., Sahoo, B.B., Patel, D. and Dash, D.K. 2013. Weed management studies in onion (Allium cepa L.). J. Crop Weed, 9 (2): 210-12. Ved Prakash, Pandey,

16. Tsolmon B, Otgonsuren M. 2014, "Results of new herbicides of August firm, from Russia" report of the contract work. UB city.

17. Bhalla, P.L. 1978. Weed competition, crop losses and chemical weed control in onion - A Review. Pestology, 11 (2): 35-39.

18. Ariunaa 0, 2017-2018 report "To define a threshold and distribution of weeds in cabbage and onion fields and development to control method them"

19. Ariunaa O. "The dominant weeds in the cropland" Handbook, Ulaanbaatar. p:37-68

20. Grubov V.I (2008). "The vascular of Mongolia”, p: 87-154, Ulaanbaatar. 